\title{
Spontaneous teeth migration after periodontal treatment in the patients with drug-induced gingival enlargement
}

\author{
Youn-Kyung Choi', Kyoung-Hwa Jung ${ }^{1}$, So-Yeun Kim¹, Hye-Mi Jeon', Jeomil Choi', Ju-Youn Lee ${ }^{2}$, \\ Ji-Young Joo², Eun-Young Kwon, ${ }^{1,2 *}$ \\ 'Dental Clinic Center, Pusan National University Hosptial, Busan, Republic of Korea \\ ${ }^{2}$ Department of Periodontology, School of Dentistry, Pusan National University, Yangsan, Republic of Korea
}

Anticonvulsants, calcium channel blockers and immunosuppressants are representative drugs related with gingival enlargement. Clinical signs and symptoms caused by drug-induced gingival enlargment frequently appear within 1 to 3 months after medication. At initial stage, it is limited to attached gingiva but may extend coronally and interfere with esthetics, mastication and speech. Interproximal spaces are common beginning area and pathologic teeth migration could be occurred by the lesion. Withdrawal or substitution of medication would be the most effective treatment of drug-induced gingival enlargement. However, periodontal treatment and further supportive periodontal therapy should be provided where change in medication is impossible. The present study reports the cases which show the resolution of inflammation with spontaneous teeth migration without change in medication. In all cases discussed in this report could be efficiently managed with proper periodontal treatment and further supportive periodontal therapy. (J Dent Rehabil Appl Sci 2017;33(1):34-41)

Key words: gingival overgrowth; periodontal diseases

\begin{abstract}
서론
"치은비대(gingival enlargement)" 또는 "치은과증식 (gingival overgrowth)"은 이전에 "gingival hyperplasia" 또는 “gingival hypertrophy”라고 불리었으며, 이들은 모 두 약물과 연관된 치은 병소를 가리키는 용어이다. 그러 나 이전의 용어들은 약물에 의해 변화된 치은의 조직학 적 구성을 정확히 반영하지 못하였다. 치은비대와 연관된 대표적인 3 가지 약물은 항경련제, 칼슘 길항제, 면역 억 제재 등이다. 비록 이러한 약물의 약리학적 효과는 다르 고 다양한 일차적 목표 조직(primary target tissues)에 작 용하나, 3가지 모두 이차적 목표 조직(secondary target
\end{abstract}

*Correspondence to: Eun-Young Kwon

Clinical Assistant Professor, Department of Periodontology, Dental Center, Pusan National University Hospital, Gudeok-ro 179, Seo-gu, Busan, 49241, Republic of Korea Tel: +82-51-240-7429, Fax: +82-51-240-7706, E-mail: betteryoung@hanmail.net Received: January 3, 2017/Last Revision: January 17, 2017/Accepted: January 28,2017 tissue) 즉, 치은 결합조직에 유사하게 작용하며, 이로 인 해 공통의 임상적, 조직 병리학적 소견을 유발하는 것으 로 보인다. ${ }^{1}$

Phenytoin은 1930년대에 최초로 소개된 이후 경련 치 료를 위한 약물로 사용되고 있다. 비록 phenytoin과 연 관된 약물성 치은비대의 유병률은 다양하게 보고되고 있 으나, phenytoin으로 치료한 환자에서 대략 $50 \%$ 정도로 보고되고 있다. ${ }^{2}$ 칼슘 길항제의 대표적인 약물로는 1980 년대에 소개된 nifedipine이 있으며, 여러 역학 연구에서 nifedipine을 복용하는 사람의 약 $6 \%$ 정도에서만 상당 한 치은비대를 관찰하였다. 또한 같은 칼슘 길항제라도 amlodipine은 그 빈도가 약 절반 정도로 떨어지는 것으

Copyright(C 2017 The Korean Academy of Stomatognathic Function and Occlusion. (c) It is identical to Creative Commons Non-Commercial License. 
로 알려져 있다. ${ }^{3}$ Cyclosporine A (CsA)는 류미티스 관절 염과 같은 자가면역 질환을 치료하기 위해서 뿐 만 아니 라 장기 이식 후 거부 반응을 방지 하기 위해 널리 쓰이고 있는 약물이다. CsA로 인한 치은비대의 유병률은 25에 서 $30 \%$ 정도로 보고되는데, 어린이에서는 $70 \%$ 이상으 로 높게 나타나는 경향이 있다. ${ }^{4}$

이러한 약물을 복용하는 환자들에서 치은비대의 원인 은 불량한 치태 조절과 연관되어 있으며 특히 염증성 치 은증식이 있는 환자에서 $\mathrm{CsA}$ 를 복용할 경우 심각한 치 은비대가 더 잘 발생하는 것으로 나타났다. 또한, 동시에 여러 약물을 복용할 경우 치은비대에 영향을 주는데, 칼 슘 길항제를 복용하고 있는 환자가 $\mathrm{CsA}$ 를 동시에 복용 할 경우 CsA만 단독으로 복용하는 경우 보다 치은비대 의 심각도가 크게 증가할 수 있다. 그러나 비대의 심각도 와 phenytoin, nifedipine, $\mathrm{CsA}$ 의 복용 용량과는 큰 연관 성은 없는 것으로 알려져 있다. ${ }^{1,5}$

약물성 치은비대의 임상적 특징은 관련된 약물로 치료 를 시작한 후 1 개월에서 3 개월 사이에 흔히 나타난다. ${ }^{6}$ 섬유성 치은비대는 초기에는 부착 치은에 한정되나, 이 후 치관측으로 확장되어 심미성을 손상시키고 발음과 저 작에 장애를 준다. 이로 인하여 구강 위생 관리를 어렵게 만들고 구내 감염, 치아 우식 그리고 치주 질환에 취약한 환경을 만든다. 치간 부위에서 시작되는 경우가 많고 전 치부 순면에서 더욱 흔하게 발견되며, 치아의 병적인 이 동을 유발시키기도 한다. ${ }^{7}$

본 연구에서는 약물성 치은비대로 병적인 치아 이동이 일어난 경우, 치주 치료로 염증이 해소 되면서 자발적으 로 치아 이동이 함께 일어난 증례를 보고하고자 한다.

\section{증례보고}

\section{1. 증례 1}

46세의 남자 환자가 잇몸이 부어서 피가 나고 식사하 기 힘들다는 주소로 치주과에 내원하였다. 환자의 구내 검사시 상악 및 하악 전치부에서 붉은 발적과 치은비대 가 관찰되었다. 오랜 기간 치태 조절이 잘 되지 못해 치 주낭 탐침시 출혈과 치은비대에 의한 병적인 치아 이동 이 관찰되었다(Fig. 1). 전신 병력 문진 결과 환자는 8년 전부터 고혈압으로 칼슘 길항제인 nifedipine을 복용하 고 있었다. 방사선 사진상 전반적인 중등도의 수평적 골 소실이 있었으나 국소적인 깊은 수직적 골소실은 관찰되 지 않았다(Fig 2). 진단은 약물성 치은비대로 내리고, 내 과의사에게 1 차적인 원인인 칼슘 길항제를 다른 성분의 약물로 대체 가능한지 의뢰하였다. 그러나 의뢰 결과 현 재 복용하고 있는 약물이 환자에게 혈압 조절에 가장 효 과적으로 반응하므로 가급적 대체하지 말 것을 권고 받 았다. 따라서 약물 대체 없이 치주치료만으로 대응하기 로 결정하였다. 원활한 치태 조절을 위한 구강 위생 교육 을 동반한 전악에 걸친 치석제거술 및 치근활택술을 시 행하였다(Fig. 3). 이후 상악은 치은비대가 거의 해소 되 었으나 하악은 치간 유두 부위에서 치은비대가 잔존하여 반복적인 치근활택술을 시행하였다. 이후 치은비대는 모 두 해소되었으며 6개월까지 안정적으로 유지되었다(Fig. 4). 1년까지 약물 교체 없이 치주 치료 결과 안정적인 치 은 상태를 보였으며 치은 비대로 유발된 치간 공간이 많 이 줄어든 양상을 보였다(Fig. 5). 추후 교정치료로 적극 적인 치아 배열을 고려해보기로 하였다.

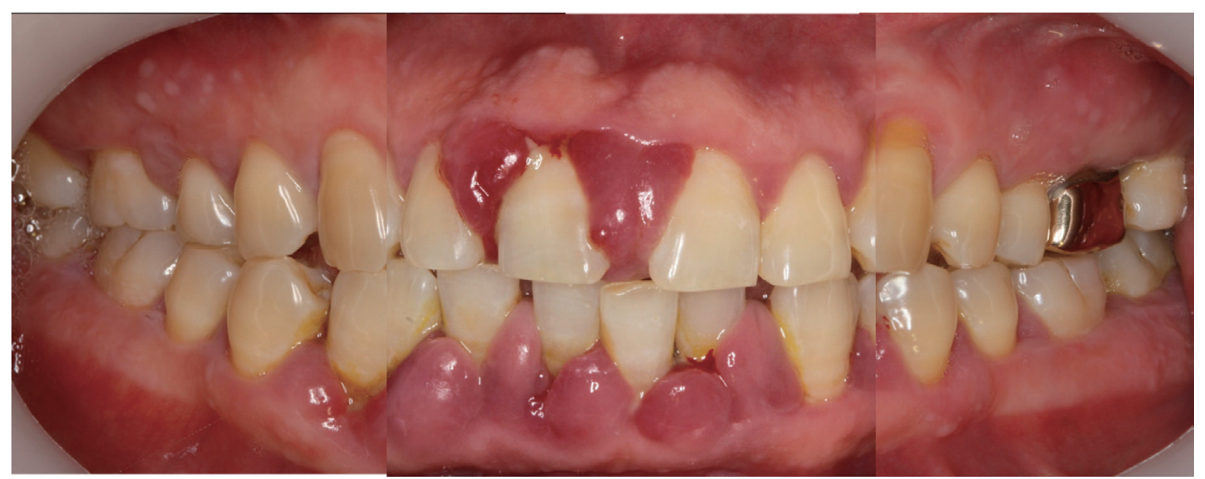

Fig. 1. Pretreatment clinical view of case 1 . Note the gingival overgrowth and pathologic tooth movement. 


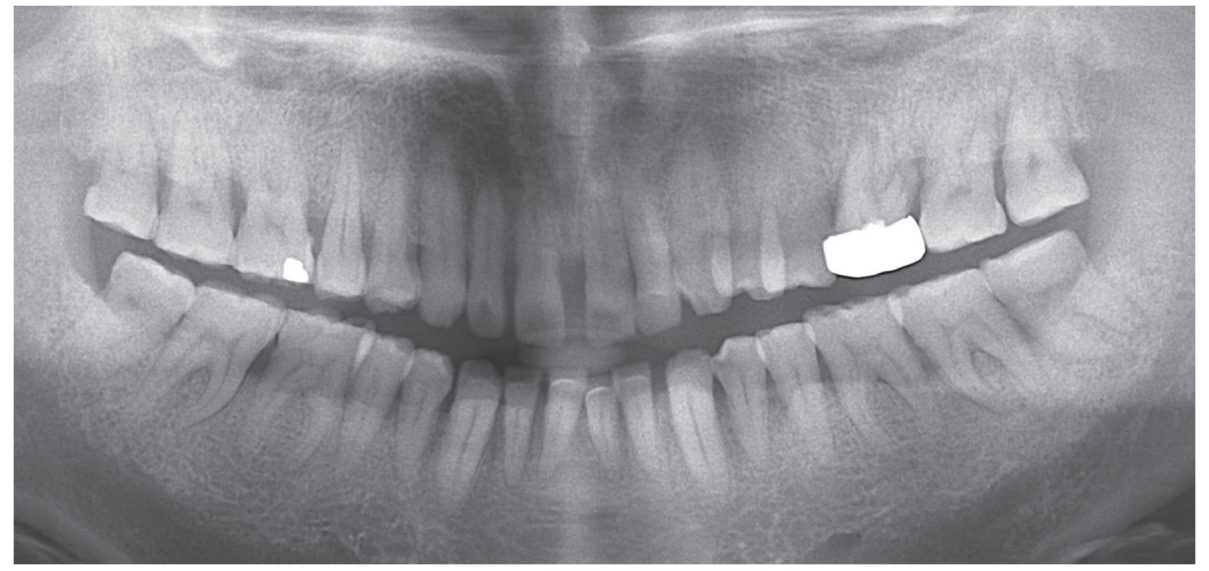

Fig. 2. Pretreatment radiograph of case 1 . Generalized horizontal bone loss and calculus deposit were found.

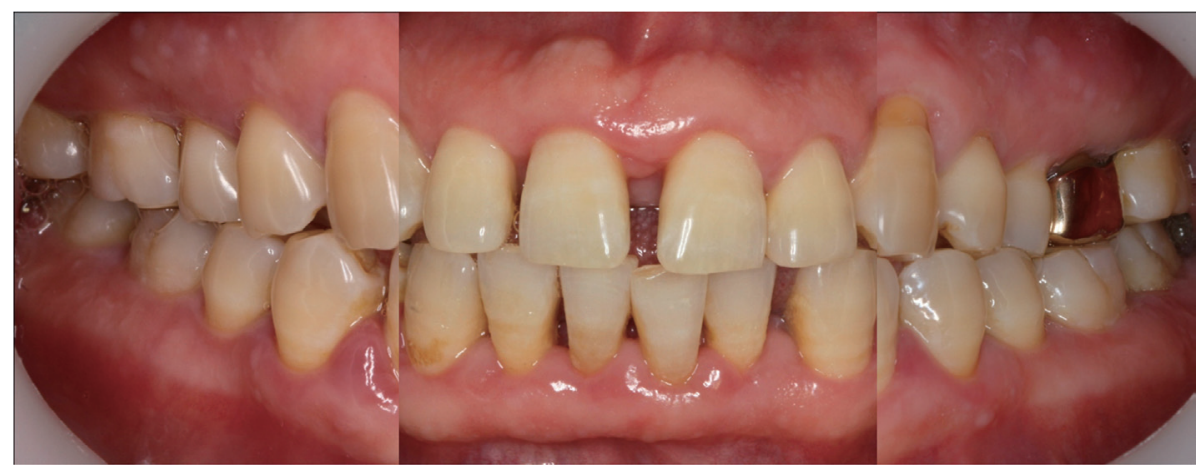

Fig. 3. Posttreatment of case 1 . After scaling and root planing, gingival overgrowth was subsided at upper anterior area but remained at lower anterior area.

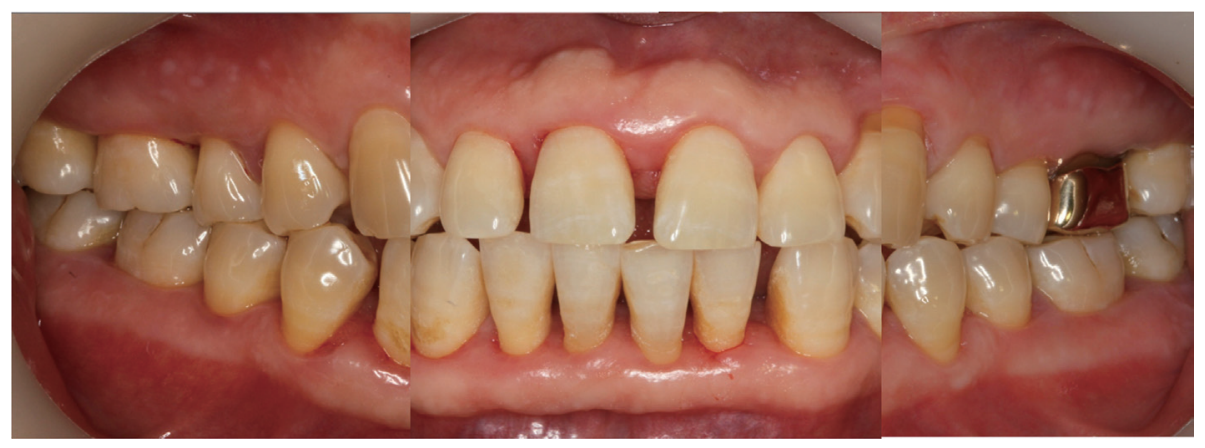

Fig. 4. Posttreatment at 6 month of case 1 . Note the remission of gingival overgrowth and improvement of oral hygiene.

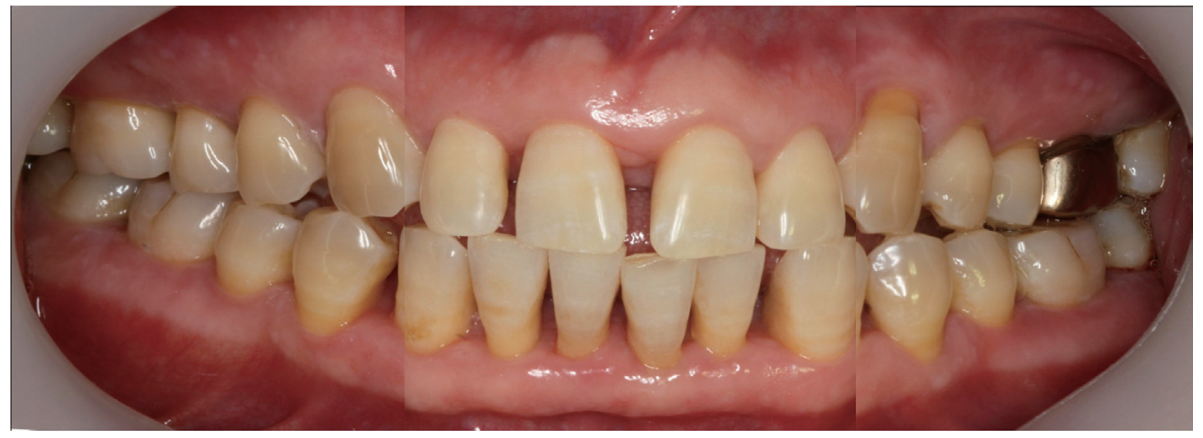

Fig. 5. Posttreatment at 1 year of case 1. Note no relapse of gingival overgrowth and maintenance of gingival health. Pathologic tooth movement was corrected spontaneously and further orthodontic treatment was recommended. 


\section{2. 증례 2}

68세의 여자 환자로 계속 잇몸이 자란다는 주소로 치 주과에 내원하였다. 구내 검사 결과 전악에 걸친 치은 비대가 관찰되었고 치주낭 탐침시 출혈과 하악 전치부 의 1 도의 동요도 및 병적인 치아 이동이 관찰되었다(Fig. 6). 전신 병력 문진 결과 환자는 10 년전부터 고혈압으로 nifedipine을 복용하고 있었다. 방사선 사진상 전반적인 중등도의 수평적 골소실이 있었으나 국소적인 깊은 수직 적 골소실은 관찰되지 않았다(Fig 7). 진단은 약물성 치 은비대로 내리고, 내과 의사에게 칼슘 길항제를 다른 성
분의 약물로 대체 가능한지 의뢰하였다. 내과 의사의 대 체 가능하다는 답변과 함께 바로 다른 성분으로 대체하 였으나 환자는 두통 및 혈압 조절의 어려움을 호소하며 원래 복용하던 nifedipine의 복용을 강력히 희망하였다. 따라서, 약물 대체 없이 치주치료만으로 대응하기로 결 정하였다. 구강 위생 교육과 함께 전악에 걸친 치석제거 술 및 치근활택술이 시행되었다(Fig. 8). 이후 잔존한 치 은비대 해소를 위해 반복적인 치근활택술을 시행하였으 며(Fig. 9), 그 결과 12개월까지 안정적으로 유지되었고 하악 전치부의 병적인 치아 이동이 자발적으로 해소되었 다(Fig. 10).

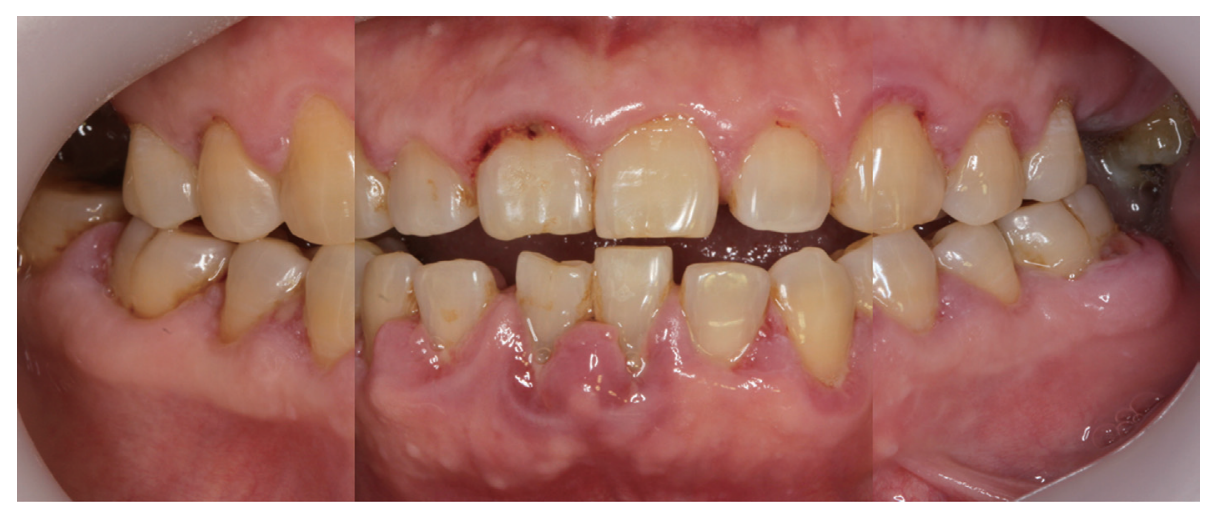

Fig. 6. Pretreatment clinical view of case 2. Note the gingival overgrowth and erythema.

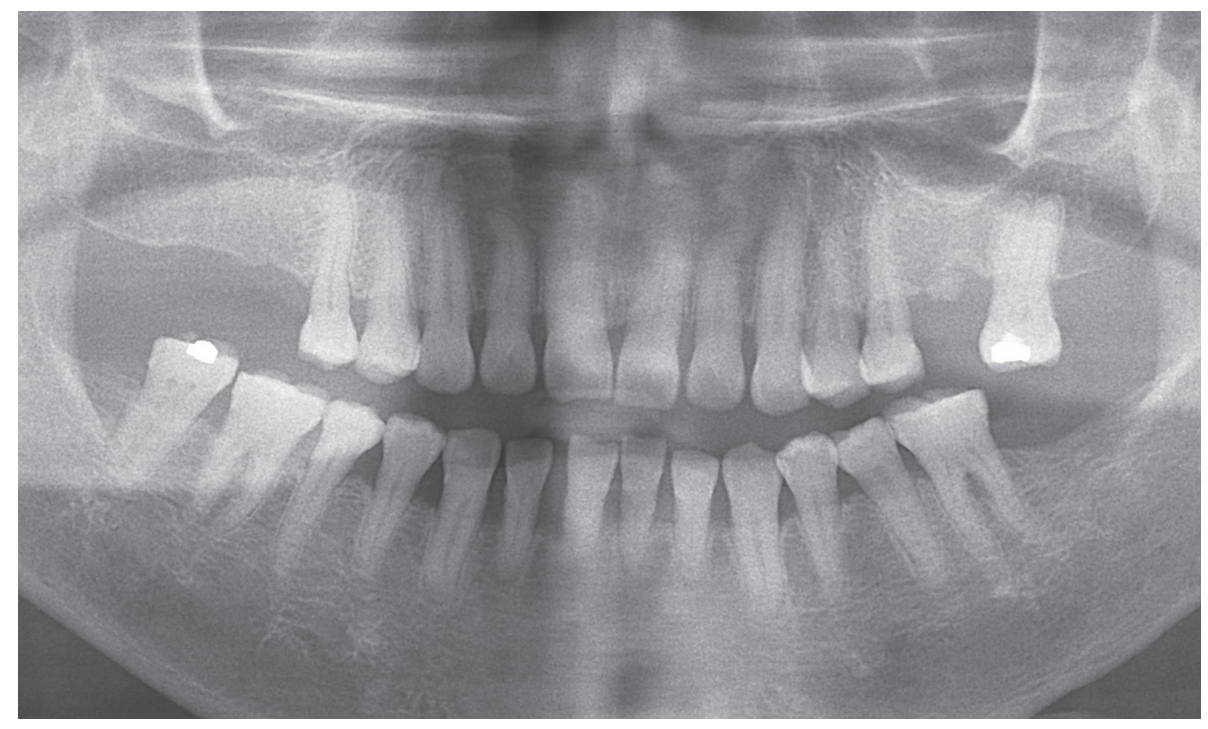

Fig. 7. Pretreatment radiograph of case 2 . Generalized horizontal alveolar bone loss and multiple teeth missing were found. 


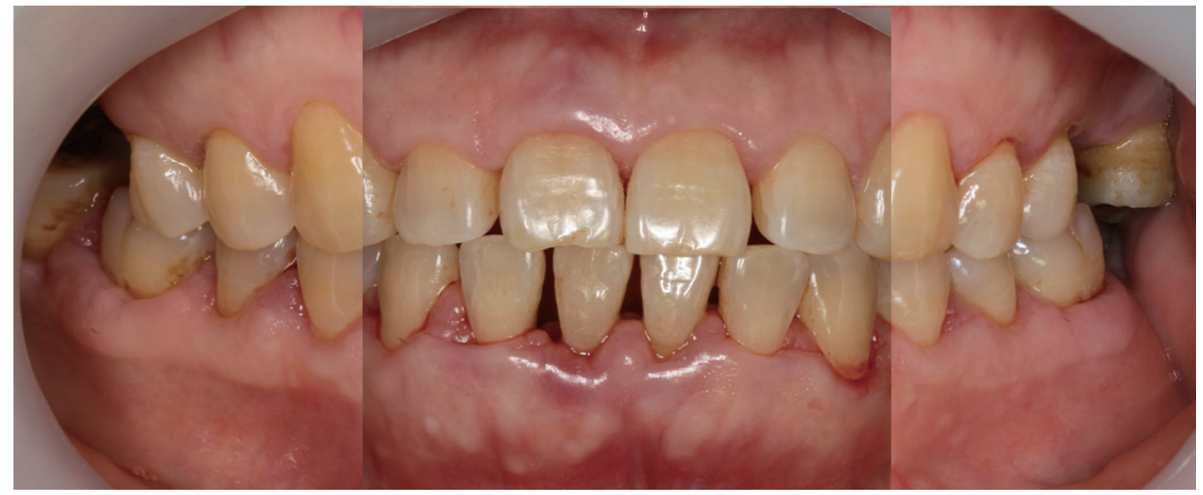

Fig. 8. Posttreatment of case 2. After scaling and root planing, gingival overgrowth was remained at lower anterior and right molar area.

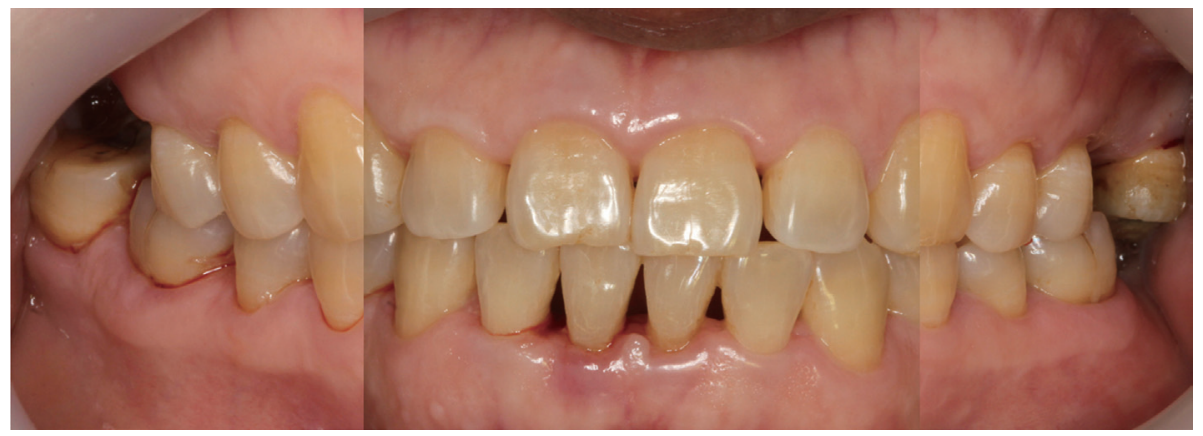

Fig. 9. Posttreatment at 6 month of case 2. Note the remission of gingival overgrowth and improvement of oral hygiene.

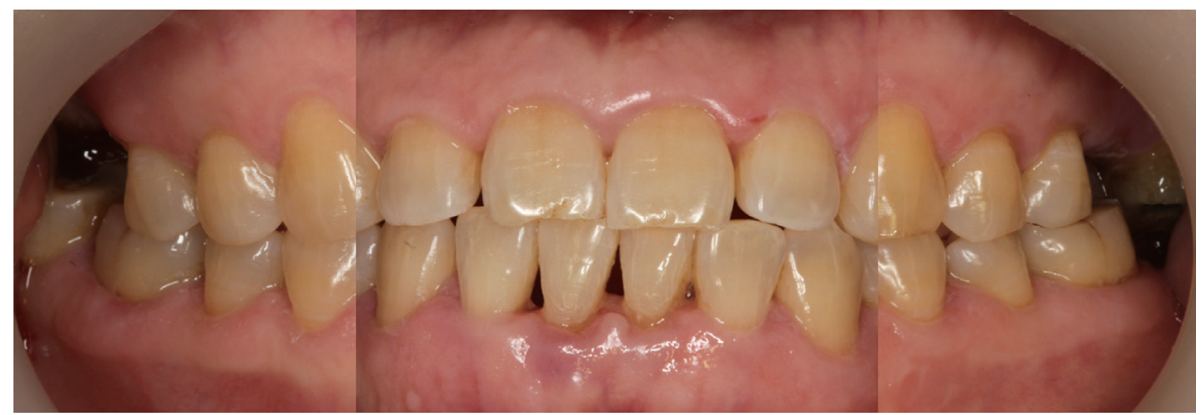

Fig. 10. Posttreatment at 1 year of case 2. Note no relapse of gingival overgrowth and maintenance of gingival health. Pathologic tooth movement was corrected spontaneously.

\section{고찰}

치석제거술과 치근활택술은 치은비대를 효과적으로 줄여줄 수 있는데 비외과적 처치의 일차적 목표는 치은 조직에서 염증성 구성 요소를 감소시키고 수술의 필요 성을 감소시키는 데 있다. ${ }^{8}$ 치태와 치은비대의 발현간 관 련성은 불분명한데, 치태의 축적이 치은의 변화의 원인 이 되거나 결과가 된다는 것은 아직도 논쟁 중이다. 치태
조절이 약물성 치은비대 치료에 도움을 줄 수는 있으나 예방은 하지 못하고 구강 위생 교육만으로는 치은비대 의 발생을 완전히 예방하지는 못하기 때문이다. ${ }^{9}$ 그럼에 도 불구하고, 원활하게 이루어지는 치태 조절은 치은 조 직에서 염증 물질을 감소시키고 치은비대를 받아들여질 만한 수준으로 조절하여 외과적 처치를 더욱 쉽게 만든 다. ${ }^{10}$ 또한, 철저한 치태 조절과 완전한 치석제거술과 치 근활택술로 약물성 치은비대의 상당한 감소와 조절이 얻 
어질 수 있다. ${ }^{11}$

비록, 다양한 비외과적인 치료법들이 약물성 치은비대 의 치료에 다양하게 이용되고 있으나, 외과적 처치가 여 전히 가장 흔히 사용되는 치료법이다. 외과적 처치는 치 은비대가 심각할 때만 옹호되며, 전치부 순면 치은이 영 향을 받는 경우가 많기 때문에, 기능적인 이유 보다는 심 미적인 이유로 흔히 시행된다. 현재 흔히 사용되는 외과 적 치료에는 치은절제술, 치주판막술, 전기응용 외과수 술(electrosurgery), 레이저를 이용한 절제 등이 있다. 그 중에서도 가장 전형적인 외과적 시술은 외사선 절개를 동반한 치은절제술이나, 전체적인 또는 국소적인 내사 선 절개를 동반한 치은 절제술은 대안으로 제시된다. 이 것은 큰 노출된 결합조직 창상을 피하여 술후 통증과 출 혈을 최소화 시키는 이점이 있다. 치조골과 부착 소실까 지 동반된 경우에는 치주판막술이 적응증이 되며, 이는 개방 창상을 줄여주어서 술후 불편감과 출혈을 감소시켜 줄 수 있다. ${ }^{12}$ 간혹 지혈 목적으로 전기응용 외과수술을 시행하기도 하나, 주위 조직의 열로 인한 괴사를 유발하 여 치유를 지연시킬 수 있다. 그러나 어린이나 장애인 또 는 지혈이 잘 되지 않는 환자에서는 외과적 처치 자체가 어렵기 때문에 전기응용 외과수술이 대체 치료로 이용될 수 있다. ${ }^{13}$ 레이저는 절단 능력이 뛰어나며 레이저 절개 선을 따라서 응고된 조직층을 형성시켜 치유를 촉진시킨 다. 상대적으로 출혈이 적고 절개선이 정확하고 수술 부 위의 멸균, 부종과 상처 형성의 최소화 등의 이점 뿐 만 아니라, 술후 재발이 낮다는 보고도 있는데, 이는 치유 과정에서 치은 섬유모세포에 의한 콜라겐 형성을 감소시 키거나 지연시키기 때문이다. ${ }^{14}$

결론적으로, 외과적 처치는 여전히 주요한 치료법이고 특히 치은절제술은 가장 주요한 치료이다. 그러나 수술 을 한다고 해서 아예 재발을 안 하는 것은 아니며, 재발 의 중요한 결정 인자는 젊은 연령, 치은 염증, 유지 관리 를 위한 정기적 내원의 불응 등으로 밝혀졌다. 또한 나열 된 약물들을 대부분 만성적으로 사용하는 경우가 많기 때문에 항상 재발의 위험도가 높을 수 밖에 없다. ${ }^{12}$ 따라 서, 무엇보다 외과적 처치 이후 치은 염증 해소를 위한 구 강 위생 관리 및 정기 점검이 반드시 뒷받침 되어야 한다. 특히 3개월 간격의 치주 유지 관리는 약물성 치은비대가 발생한 환자에서 추천된다. ${ }^{1}$

약물성 치은비대의 가장 효과적인 치료는 약물의 중 단이나 대체이며, 이러한 중단이나 대체 이후 1 주에서 8 주 정도 지나면 치은비대가 해소된다는 증례 보고가 존
재한다. ${ }^{15}$ Phenytoin을 gabapentin, topiramate와 같은 새로운 항경련제로 대체하는 것은 치은비대가 심한 경 우 좋은 치료 선택이 된다. Nifedipine을 diltiazem 또는 verapamil과 같은 다른 항고혈압 제제로 대체하는 것은 치은비대의 감소를 야기할 것이다. 특히 amlodipine은 nifedipine과 똑같은 dihydropridines이나 복용시 치은 비대의 유병률은 nifedipine의 절반 정도 밖에 되지 않는 다. ${ }^{3}$ 또한 CsA를 tacrolimus로 대체하는 것은 치은비대의 심각도를 감소시키고 수술적 처치를 할 필요성도 감소시 킨다. ${ }^{12}$ 따라서 만일 가능하다면, 약물을 대체하고 치태 와 치석과 같은 국소 염증 인자들의 효과적인 조절이 치 료 목표가 될 것이다. 그러나 모든 환자가 이러한 치료가 가능한 것은 아니며, 약물 교체는 새로운 약물이 고혈압 등 그들의 기존 질환을 조절하는데 더 나은 이점을 줄 수 있을 때만 가능하며, 임상적으로 심각한 치은비대를 보 이거나 외과적 처치가 큰 위험 부담이 될 때 또는 치은절 제술 이후에도 재발 위험이 클 때만 고려해야 한다. 모든 약물은 원치 않는 효과를 동반하며, 치은비대의 병적인 상태가 새로운 약물로 대체했을 경우 또다시 발생하는 원치 않는 효과와 비교하여 평가되어야 한다.

본 증례의 환자들도 약물성 치은비대를 위한 치료에서 칼슘 길항제의 대체가 어려워 결국은 약물 대체 없이 치 주치료만으로 대응하였다. 치주치료 이후 심미적, 기능적 으로 향상을 보였으며, 특히 병적으로 이동했던 치아들 이 치주치료만으로 자발적으로 재위치 되었다. 이것은 치 은증식에 따른 병적인 치아 이동이 외상성 교합을 야기 하여 파골세포 활성화를 가속화시켜 치주 질환의 진행뿐 만 아니라 치아의 병적인 이동을 유발시키는데, ${ }^{16}$ 치주 치 료로 중격간 교원 섬유가 회복되어 얻어진 결과로 생각 된다. ${ }^{17}$

\section{결론}

약물성 치은 비대를 위한 치료에서 근본적인 원인인 약 물 대체가 선행되면 재발의 위험 등은 훨씬 낮아지는 이 점이 있으나, 대체가 어려울 때는 치주치료와 철저한 유 지관리가 병행되어야만 한다. 따라서, 약물성 치은비대 는 예방할 수는 없으나, 국소 인자들을 제거하고 철저한 치태 조절과 정기적인 치주 유지 관리를 통해 개선될 수 있다. 본 증례의 환자들도 치주치료 이후 3 개월 마다 정 기 점검을 통해 안정적으로 유지될 수 있었다. 


\section{Acknowledgements}

본 연구는 2017년도 부산대학교병원 임상연구비 지원 으로 이루어졌음.

\section{ORCID}

Youn-Kyung Choi http://orcid.org/0000-0003-14912986

Kyoung-Hwa Jung http://orcid.org/0000-0002-83050016

So-Yeun Kim http://orcid.org/0000-0002-3043-2723 Hye-Mi Jeon http://orcid.org/0000-0003-0007-5662 Jeomil Choi http://orcid.org/0000-0002-7491-6711 Ju-Youn Lee http://orcid.org/0000-0002-0772-033X Ji-Young Joo http://orcid.org/0000-0002-4050-5797 Eun-Young Kwon http://orcid.org/0000-0001-95550360

\section{References}

1. Dongari-Bagtzoglou A; Research, Science and Therapy Committee, American Academy of Periodontology. Drug-associated gingival enlargement. J Periodontol 2004;75:1424-31.

2. Casetta I, Granieri E, Desiderá M, Monetti VC, Tola MR, Paolino E, Govoni V, Calura G. Phenytoin-induced gingival overgrowth: a community-based cross-sectional study in Ferrara, Italy. Neuroepidemiology 1997;16:296-303.

3. Ellis JS, Seymour RA, Steele JG, Robertson P, Butler TJ, Thomason JM. Prevalence of gingival overgrowth induced by calcium channel blockers: a community-based study. J Periodontol 1999;70:637.

4. Boltchi FE, Rees TD, Iacopino AM. Cyclosporine A-induced gingival overgrowth: a comprehensive review. Quintessence Int 1999;30:775-83.

5. Hassell TM, Hefti AF. Drug-induced gingival overgrowth: old problem, new problem. Crit Rev Oral Biol Med 1991;2:103-37.

6. Meraw SJ, Sheridan PJ. Medically induced gingival hyperplasia. Mayo Clin Proc 1998;73:1196-99.

7. Hallmon WW, Rossmann JA. The role of drugs in the pathoge1nesis of gingival overgrowth. A collective review of current concepts. Periodontol 2000 1999;21:176-96.

8. Somacarrera ML, Lucas M, Scully C, Barrios C. Effectiveness of periodontal treatments on cyclosporine-induced gingival overgrowth in transplant patients. Br Dent J 1997;183:89-94.

9. Seymour RA, Smith DG. The effect of a plaque control programme on the incidence and severity of cyclosporin-induced gingival changes. J Clin Periodontol 1991;18:107-10.

10. Kantarci A, Cebeci I, Tuncer O, Carin M, Firatli E. Clinical effects of periodontal therapy on the severity of cyclosporin A-induced gingival hyperplasia. J Periodontol 1999;70:587-93.

11. Hancock RH, Swan RH. Nifedipine-induced gingival overgrowth. Report of a case treated by controlling plaque. J Clin Periodontol 1992;19:12-4.

12. Mavrogiannis M, Ellis JS, Thomason JM, Seymour RA. The management of drug-induced gingival overgrowth. J Clin Periodontol 2006;33:434-9.

13. Walker CR Jr, Tomich CE, Hutton CE. Treatment of phenytoin-induced gingival hyperplasia by electrosurgery. J Oral Surg 1980;38:306-11.

14. Goharkhay K, Moritz A, Wilder-Smith P, Schoop U, Kluger W, Jakolitsch S, Sperr W. Effects on oral soft tissue produced by a diode laser in vitro. Lasers Surg Med 1999;25:401-6.

15. Khocht A, Schneider LC. Periodontal management of gingival overgrowth in the heart transplant patient: a case report. J Periodontol 1997;68:1140-6.

16. Jin LJ, Cao CF. Clinical diagnosis of trauma from occlusion and its relation with severity of periodontitis. J Clin Periodontol 1992;19:92-7.

17. Gaumet PE, Brunsvold MI, McMahan CA. Spontaneous repositioning of pathologically migrated teeth. J Periodontol 1999;70:1177-84. 


\section{약물성 치은비대로 인한 병적인 치아 이동이 있는 환자에서 치주치료 이후 자발적 치아 이동을 보인 증례}

최윤경 ${ }^{1}$, 정경화 ${ }^{1}$, 김소연 ${ }^{1}$, 전혜미 ${ }^{1}$ 최점일 ${ }^{2}$, 이주연 ${ }^{2}$, 주지영 ${ }^{2}$, 권은영 ${ }^{1,2 *}$

${ }^{1}$ 부산대학교병원 치과진료센터

${ }^{2}$ 부산대학교 치의학전문대학원 치주과학교실

치은비대와 연관된 대표적인 3가지 약물은 항경련제, 칼슘 길항제, 면역 억제재 등이다. 약물성 치은 비대를 위한 치료에 서 근본적인 원인인 약물 대체가 선행되면 재발의 위험 등은 훨씬 낮아지는 이점이 있으나, 대체가 어려울 때는 치주치료 와 철저한 유지관리가 병행되어야만 한다. 본 연구에서는 약물성 치은비대로 병적인 치아 이동이 일어난 경우, 약물 교체 없이 치주 치료로 염증이 해소 되면서 자발적으로 치아 이동이 함께 일어난 증례를 보고하고자 한다. 본 증례의 환자들 도 치주치료 이후 적극적인 정기 점검을 통해 안정적으로 유지될 수 있었다.

(구강회복응용과학지 2017;33(1):34-41)

주요어: 치은비대; 치주치료; 유지관리

*교신저자: 권은영

(49241)부산시 서구 구덕로 179 부산대학교병원 치과진료센터 치주과

Tel: 051-240-7429 | Fax: 051-240-7706 | E-mail: betteryoung@hanmail. net

접수일: 2017년 1월 3일 | 수정일: 2017년 1월 17일 | 채택일: 2017년 1월 28일 